ORIGINAL ARTICLE

\title{
PERBEDAAN KUALITAS HIDUP PASIEN USIA LANJUT SEBELUM DAN SETELAH OPERASI KATARAK
}

Adelia Lisnawati $^{1 *}$, Nur Khoma Fatmawati ${ }^{2}$, Meiliati Aminyoto ${ }^{3}$

Fakultas Kedokteran, Universitas Mulawarman

*Correspondent author: lisnawatiadelia30@gmail.com

ARTICLE INFO
Article history:
Received:
February, 72020
Received in revised form:
February, 142020
Accepted:
February, 162020

\section{Keywords:}

Quality of life, cataract, cataract surgery, elderly

\begin{abstract}
Cataract is a condition when the lens become cloudy and often occurs in elderly patients. Cataract is the leading cause of visual impairment and blindness in the world. Cataract can reduce productivity and social life, that will decrease the quality of life in elderly patients. It also reduces the visual acuity leading to decreasing visual function and the quality of life. This disease can change physical, cognitive and psychosocial life. This study aimed to analyze the difference of quality of life in elderly patients before and after cataract surgery at SMEC eye clinic in Samarinda. This study was observational analytic study. Data were taken from interview the patients with visual function questionnaire 14 (VFQ 14) and from the medical record of SMEC eye
\end{abstract}

$=95,35)$ and there was significant improvement of the visual acuity after cataract surgery $(p=0,000)$. Based on these results it can be concluded that there were difference of quality of life in elderly patients before and after cataract surgery.

@ 2020 Medical and Health Science Journal. 10.33086/mhsj.v4i1.1449 


\section{INTRODUCTION}

Mata merupakan salah satu alat indera yang penting bagi manusia untuk melihat dan menyerap berbagai informasi visual yang digunakan untuk melaksanakan berbagai macam kegiatan. Gangguan terhadap penglihatan dan kebutaan masih banyak terjadi, mulai dari gangguan ringan hingga gangguan yang berat dan menjadi masalah kesehatan yang cukup serius di dunia termasuk Indonesia. ${ }^{1}$

Global Data on Visual Impairments 2010, menyebutkan bahwa di seluruh dunia terdapat 285 juta orang dengan gangguan penglihatan. Tiga puluh sembilan juta orang buta dan 246 juta penyandang low vision. Kebutaan akibat katarak masih mendominasi tingkat kebutaan di Indonesia. ${ }^{2}$

Penyakit katarak merupakan penyakit mata yang ditandai dengan kekeruhan lensa mata sehingga mengganggu proses masuknya cahaya ke mata. Katarak dapat disebabkan karena terganggunya mekanisme kontrol keseimbangan air dan elektrolit, denaturasi protein lensa atau gabungan keduanya. ${ }^{3}$ Katarak umumnya merupakan penyakit yang sering terjadi pada usia lanjut, akan tetapi dapat juga akibat kelainan kongenital, atau penyulit penyakit mata lokal menahun. ${ }^{4}$

Seseorang akan mengalami perubahan dalam segi fisik, kognitif, dan kehidupan psikososial pada usia lanjut, sehingga menyebabkan pentingnya harapan hidup dan kualitas hidup pada usia ini. Penyakit tersebut menyebabkan penurunan produktivitas dan kehidupan sosial sehingga menyebabkan rendahnya kualitas hidup pada usia ini. ${ }^{5}$

Berbagai penelitian yang ada menunjukkan bahwa gangguan penglihatan dan kebutaan dapat mengakibatkan menurunnya kualitas hidup (quality of life), yang terlihat dari berkurangnya kemampuan seseorang untuk melakukan pekerjaan, mengisi waktu luang, atau melakukan aktivitas harian (activities of daily living). Oleh karenanya penilaian skor quality of life $(Q o L)$ sangat bermanfaat untuk menentukan dampak yang dialami oleh pasien dengan ganggguan penglihatan. ${ }^{6}$

Karena jumlah penderita katarak dan angka kebutaan akibat penyakit katarak di dunia maupun di Indonesia masih cukup tinggi dan terus mengalami peningkatan, maka perlu diadakannya penelitian untuk mengetahui perbedaan kualitas hidup pasien usia lanjut sebelum dan setelah operasi katarak.

\section{METHODS}

Penelitian ini merupakan penelitian analitik observasional yang dilakukan di klinik mata SMEC Samarinda. Populasi dalam penelitian ini adalah semua pasien katarak di klinik mata SMEC Samarinda. Variabel yang diteliti dalam penelitian ini meliputi jenis kelamin, visus, usia, dan kualitas hidup pasien sebelum dan setelah menjalani operasi katarak. Penelitian ini dilakukan dengan mengambil data primer dan data sekunder. Data sekunder berasal dari rekam medik pasien katarak dan data primer berasal dari kuesioner visual function 14 (VF 14), hasil wawancara dengan pasien setelah operasi katarak di klinik mata SMEC Samarinda.

\section{RESULT}

Berdasarkan penelitian yang dilakukan pada 46 responden, maka didapatkan hasil sebagai berikut :

Tabel 1 Gambaran Distribusi Jenis Kelamin Pasien Katarak

\begin{tabular}{ccc}
\hline $\begin{array}{c}\text { Jenis } \\
\text { Kelamin }\end{array}$ & Frekuensi & $\begin{array}{c}\text { Persentase } \\
\mathbf{( \% )}\end{array}$ \\
\cline { 1 - 1 } Laki-laki & 19 & 41,3 \\
Perempuan & $\underline{27}$ & $\underline{58,7}$ \\
\hline Jumlah & $\underline{46}$ & $\underline{100}$ \\
\hline
\end{tabular}

Berdasarkan hasil penelitian ini, diketahui dari 46 responden, jenis kelamin yang paling banyak adalah perempuan yaitu sebanyak 27 pasien $(58,7 \%)$ dan lakilaki sebanyak 19 pasien $(41,3 \%)$. 
Tabel 2 Gambaran Distribusi Usia Pasien Katarak

\begin{tabular}{ccc}
\hline Usia & Frekuensi & $\begin{array}{c}\text { Persentase } \\
(\boldsymbol{\%})\end{array}$ \\
\cline { 2 - 3 }$<65$ tahun & 12 & 26,1 \\
$65-70$ tahun & 21 & 45,7 \\
$70-75$ tahun & 7 & 15,2 \\
$75-80$ tahun & 3 & 6,5 \\
$>80$ tahun & 3 & 6,5 \\
Jumlah & 46 & 100 \\
\hline
\end{tabular}

Berdasarkan hasil penelitian ini, diketahui dari 46 responden, usia yang paling banyak adalah pada kelompok usia 65-70 tahun dimana terdapat 21 pasien $(45,7 \%)$, kemudian kelompok usia $<65$ tahun sebanyak 12 pasien $(26,1 \%)$, usia $70-75$ tahun sebanyak 7 pasien $(15,2 \%)$, usia $75-80$ tahun sebanyak 3 pasien $(6,5 \%)$ dan pasien berusia $>80$ tahun sebanyak 3 pasien $(6,5 \%)$.

Tabel 3 Gambaran Distribusi Visus Pasien Katarak Sebelum Operasi

\begin{tabular}{ccccc}
\hline \multirow{2}{*}{$\begin{array}{c}\text { Visus Pre } \\
\text { Operasi }\end{array}$} & Frekuensi & $\%$ & Frekuensi & $\%$ \\
\hline Baik & 5 & 10,9 & 2 & 4,3 \\
Sedang & 11 & 23,9 & 13 & 28,3 \\
Berat & 30 & 65,2 & 31 & 67,4 \\
\hline Jumlah & 46 & 100 & 46 & 100 \\
\hline
\end{tabular}

Berdasarkan hasil penelitian ini, diketahui dari 46 responden, didapatkan visus kedua mata pasien sebelum operasi katarak kebanyakan sudah mencapai kategori berat ketika akan dioperasi yaitu terdapat 30 pasien untuk visus oculi dekstra (VOD) $(65,2 \%)$ dan 31 pasien untuk visus oculi sinistra (VOS) $(67,4 \%)$, kemudian diikuti dengan kategori sedang sebanyak 11 pasien untuk VOD $(23,9 \%)$ dan 13 pasien untuk VOS $(28,3 \%)$ serta kategori baik sebanyak 5 pasien untuk VOD $(10,9 \%)$ dan 2 pasien untuk VOS $(4,3 \%)$.

Tabel 4 Gambaran Distribusi Visus Pasien Katarak Setelah Operasi

$\underline{\text { VOD }}$ VOS

\begin{tabular}{|c|c|c|c|c|}
\hline $\begin{array}{l}\text { Visus } \\
\text { Post } \\
\text { Operasi }\end{array}$ & Frekuensi & $\%$ & $\begin{array}{c}\text { Frekuen } \\
\text { si }\end{array}$ & $\%$ \\
\hline Baik & 36 & 78,3 & 37 & 80,4 \\
\hline Sedang & 8 & 17,4 & 8 & 17,4 \\
\hline Berat & 2 & 4,3 & 1 & 2,2 \\
\hline Jumlah & 46 & 100 & 46 & 100 \\
\hline
\end{tabular}

Berdasarkan hasil penelitian ini, diketahui dari 46 responden, didapatkan visus kedua mata pasien setelah operasi katarak kebanyakan sudah mencapai kategori baik yang jumlahnya tidak terlalu jauh beda untuk mata kanan dan mata kiri yaitu terdapat 36 pasien untuk visus oculi dekstra (VOD) $(78,3 \%)$ dan 37 pasien untuk visus oculi sinistra (VOS) $(80,4 \%)$, kemudian diikuti dengan kategori sedang sebanyak 8 pasien untuk VOD dan VOS $(17,4 \%)$ serta kategori berat sebanyak 2 pasien untuk VOD (4,3\%) dan 1 pasien untuk VOS $(2,2 \%)$.

Tabel 5 Uji Paired T Test Kualitas Hidup Sebelum dan Setelah Operasi Katarak

\begin{tabular}{ccc}
\hline & \multicolumn{2}{c}{ Kualitas Hidup } \\
\cline { 2 - 3 } & Pre Op & Post Op \\
\hline Mean & 63,65 & Mean \\
$\mathrm{T}$ & $-13,102$ & $\mathrm{~T}$ \\
p value & 0,000 & $p$ value \\
CI $(95 \%)$ & $(-36,568)-(-$ & CI $(95 \%)$ \\
& $26,823)$ &
\end{tabular}

Berdasarkan tabel 5 di atas, hasil analisis variabel kualitas hidup sebelum dan setelah operasi katarak berdasarkan uji Paired T Test diperoleh nilai $\mathrm{p}=0,000$, nilai $\mathrm{p}$ ini berarti lebih kecil dari 0,05 $(\mathrm{p}<0,05)$ yang artinya Ho ditolak dan $\mathrm{Ha}$ diterima. Sehingga secara statistik dapat disimpulkan bahwa terdapat perbedaan kualitas hidup pasien usia lanjut sebelum dan setelah operasi katarak di klinik mata SMEC Samarinda. Hasil dari tabel diatas juga menunjukkan nilai rata-rata kualitas hidup pasien sebelum operasi katarak 63,65 dan kualitas hidup setelah operasi katarak 95,35, maka dapat dinyatakan bahwa rerata tingkat kualitas hidup pasien 
usia lanjut setelah operasi katarak lebih tinggi daripada sebelum operasi katarak.

\section{DISCUSSION}

Hasil penelitian ini menunjukkan bahwa Proporsi pasien katarak dengan jenis kelamin perempuan jumlahnya lebih besar yaitu $58,7 \%$ sedangkan proporsi pasien katarak dengan jenis kelamin laki-laki hanya sebesar 41,3\%. Hal ini dikaitkan dengan usia harapan hidup perempuan yang lebih lama dimana jumlah perempuan usia lanjut lebih banyak. Adanya resiko peningkatan pasien katarak berjenis kelamin perempuan ini dapat dikarenakan efek dari berkurangnya hormon estrogen saat menopause. Teori yang ada menyatakan bahwa hormon estrogen dapat melindungi lensa terhadap proses pembentukan katarak, oleh karenanya semakin meningkatnya usia pada perempuan maka hormon estrogennya akan semakin menurun sehingga dapat meningkatkan resiko terjadinya penyakit katarak. ${ }^{7}$ Hal ini sejalan dengan hasil penelitian yang dilakukan oleh Fadhilah (2018) yang menunjukkan bahwa responden penderita katarak dengan jenis kelamin perempuan lebih banyak daripada responden dengan jenis kelamin laki-laki. ${ }^{8}$

Karakteristik usia responden sesuai dengan hasil penelitian yang dilakukan oleh Chang, et al (2011) yang menyatakan bahwa usia mempengaruhi terjadinya penyakit katarak. Dimana semakin meningkatnya usia seseoarang maka kekuatan lensanya akan cenderung berubah. Perubahan yang terjadi salah satunya adalah meningkatnya kemampuan lensa menghamburkan sinar matahari. Lensa menjadi semakin keras dan keruh karena terjadi penurunan metabolisme dalam tubuh, sehingga semakin bertambahnya usia seseorang maka resiko terjadinya penyakit katarak semakin besar pula. ${ }^{9} \mathrm{Hal}$ ini juga sejalan dengan hasil penelitian Fadhilah (2018) yang dilakukan di Balai Kesehatan Mata Makasar yang menunjukkan bahwa pasien katarak berusia ( $>57$ tahun) berjumlah lebih banyak daripada yang berusia $(<57$ tahun) dan mempengaruhi tingkat kualitas hidup mereka. ${ }^{8}$

Hasil penelitian ini menunjukkan bahwa nilai visus sebelum dan setelah operasi katarak berdasarkan uji Mc Nemar diperoleh nilai $\mathrm{p}<0,05$ yaitu nilai $\mathrm{p}=0,000$ untuk visus sebelum operasi katarak dan nilai $\mathrm{p}=0,000$ untuk visus setelah operasi katarak. Hal tersebut menunjukkan bahwa secara statistik terdapat perbedaan visus pasien usia lanjut sebelum dan setelah operasi katarak. Hal tersebut dapat dipengaruhi oleh tingkat pendidikan dan status ekonomi pasien dimana kurangnya informasi tentang kesehatan terutama penyakit katarak dan status ekonomi yang rendah cenderung membuat mereka tidak memprioritaskan pengobatan katarak sebelum keadaannya benar-benar sangat mengganggu. ${ }^{10}$ Peningkatan visual aquity (VA) pada pasien usia lanjut setelah operasi katarak sangat bermanfaat dalam mempertahankan kemampuan mereka untuk dapat melakukan aktivitas seharihari sehingga hal ini sangat mempengaruhi kehidupan sosial mereka. ${ }^{11}$

Hasil penelitian ini menunjukkan bahwa rata-rata kualitas hidup dari 46 pasien setelah operasi katarak lebih tinggi dibandingkan rata-rata kualitas hidup pasien sebelum operasi katarak yaitu 95,35 dan 63,65. Hasil penelitian ini sejalan dengan hasil penelitian yang dilakukan oleh Abdullahi, Alhassan, \& Babalola (2016) pada pasien katarak di National Eye Center, Kaduna, penelitian ini merupakan penelitian dengan menggunakan metode pemberian kuesioner Visual Function (VFs) dan kuesioner Quality of Life (QoL) pada pasien katarak sebelum operasi dan 6 minggu setelah operasi. Hasil dari penelitiannya menggunakan uji Paired $T$ Test ini menunjukkan nilai $\mathrm{p}=0,0001$ $(\mathrm{p}<0,05)$ yang berarti bahwa terdapat perbedaan kualitas hidup pasien usia lanjut sebelum dan setelah operasi katarak. ${ }^{12}$

Paula, Leonardo, Rosa, dan Silveira (2014), menyatakan bahwa nilai rata-rata skor kualitas hidup pasien usia lanjut yang 
lebih dari 70 sebelum operasi katarak biasanya tidak menunjukkan peningkatan yang jelas setelah operasi katarak dan hal tersebut berpengaruh secara langsung pada tingkat kepuasan pasien terhadap hasil operasi. Hal ini memberikan arti bahwa pasien dengan nilai rata-rata skor lebih dari 70 sebelum operasi katarak memiliki tingkat kualitas hidup yang cukup baik sehingga tidak cukup jelas terjadi peningkatan kualitas hidup setelah operasi katarak. Selain itu juga hasil penelitiannya menyebutkan bahwa skor kualitas hidup 95 menjadi indikator keberhasilan yang menunjukkan fungsi optimal pasien setelah operasi katarak. ${ }^{13}$ Karena hasil penelitian ini menunjukkan ratarata skor kualitas hidup pasien usia lanjut sebelum operasi katarak adalah 63,65, maka dapat simpulkan bahwa pasien tidak memiliki tingkat kualitas hidup yang cukup baik sebelum operasi katarak sehingga terjadi peningkatan rata-rata skor kualitas hidup setelah operasi katarak dengan nilai 95,35 yang memberikan arti bahwa pasien mampu melakukan aktivitas sehari-hari dengan fungsi yang optimal setelah operasi katarak dan hal ini berpengaruh terhadap penilaian tingkat kualitas hidup mereka.

Operasi katarak telah terbukti meningkatkan kualitas hidup pasien dalam melakukan aktivitas sehari-hari sebagai akibat dari meningkatnya VA setelah operasi katarak. Dengan demikian, seorang pasien setelah operasi katarak dapat memiliki waktu hidup yang cukup lama untuk menikmati manfaat dari peningkatan VA ini tanpa harus menderita stress atau depresi untuk dapat melakukan semua aktivitas hidup yang mereka inginkan. ${ }^{14}$

Dengan demikian, seorang pasien setelah operasi katarak dapat memiliki waktu hidup yang cukup lama untuk menikmati manfaat dari peningkatan VA ini tanpa harus menderita stress atau depresi untuk dapat melakukan semua aktivitas hidup yang mereka inginkan. ${ }^{14}$

\section{CONCLUSION}

1. Ketajaman penglihatan (visus) pasien usia lanjut sebelum operasi katarak pada kedua mata kebanyakan sudah mencapai kategori berat ketika akan dioperasi.

2. Ketajaman penglihatan (visus) pasien usia lanjut setelah operasi katarak pada kedua mata kebanyakan sudah mencapai kategori baik setelah dioperasi.

3. Pasien usia lanjut sebelum operasi katarak memiliki rata-rata kualitas hidup yang kurang baik dibandingkan setelah operasi katarak.

4. Pasien usia lanjut setelah operasi katarak memiliki rata-rata kualitas hidup yang lebih baik dibandingkan sebelum operasi katarak.

5. Terdapat perbedaan kualitas hidup pasien usia lanjut sebelum dan setelah operasi katarak di klinik mata SMEC Samarinda.

\section{REFERENCES}

1. Pusat Data dan Informasi Kementerian Kesehatan Republik Indonesia (PUSDATIN). (2014). Situasi Gangguan Penglihatan dan Kebutaan. Jakarta: Kementerian Kesehatan RI.

2. Kementerian Kesehatan Republik Indonesia (Kemenkes). (2018). Peta Jalan Penanggulangan Gangguan Penglihatan di Indonesia Tahun 20172030. Jakarta: Kementerian Kesehatan RI.

3. Astari, P. (2018). Katarak: Klasifikasi, Tatalaksana, dan Komplikasi Operasi. CDK-269, 45(10), 748.

4. Ilyas, S. (2017). Ilmu Penyakit Mata $\left(5^{\text {th }}\right.$ ed). Jakarta: Fakultas Kedokteran Universitas Indonesia.

5. Rohmah, A.I.N., Purwaningsih., \& Bariyah, K. (2012). Kualitas Hidup Lanjut Usia. Jurnal Keperawatan. 3(2). 120-132.

6. Asroruddin, M. (2014). Dampak gangguan penglihatan dan penyakit mata terhadap kualitas hidup terkait 
penglihatan (vision-releated quality of life) pada populasi gangguan penglihatan berat dan buta di Indonesia. Jakarta: Universitas Indonesia.

7. Lai, K., Cui, J., Ni, S., Zhang, Y., He, J., \& Yao, K. (2013). The Effect of Postmenopausal Hormone Use on Cataract: A Meta-Analysis. Plos One. 8. 1-10.

8. Fadhilah, N. (2018). Analisis Fa 67 ang Berhubungan Dengan Kualitas Hidup Penderita Katarak di Balai Kesehatan Mata Masyarakat Makassar. Makasar: Universitas Hasanuddin.

9. Chang, J.R., Koo, E., Agron, E., Hallak, $\begin{array}{llllll}\mathrm{J} & \mathrm{C} & \mathrm{Az} & \mathrm{D} & \ldots \mathrm{C} & \mathrm{E} Y\end{array}$ (2011). Risk factors associated with incident cataracts and cataract surgery in the Age Releated Eye Desease Study (AREDS). American Academia of Ophtalmology. 118. 2113-2119.

10. Haspiani, M. (2017). Karakteristik Penderita Katarak Senilis yang Telah di Laukan Pembedahan Katarak di Rumah Sakit Pendidikan Universitas Hasanuddin Periode 1 Januari 2017 - 30 Juni 2017. Makassar: Universitas Hasanuddin.

11. Shera, M.T., Samar, S.S., Ahmed, A.I., Bareeqa, S.B., \& Sattar, Z.B. (2018). Impact of Cataract Surgery in Restoration Vision among Patients with Poor PreOperative Vision: A Tertiary Care Experience from Developing Country. Open Journal of Surgery. 1(1). 9-15.

12. Abdullahi, S.M., Alhassan, M.B., \& Babalola, O.E. (2016). The Impact of Cataract Surgery on Subjective Visual Functions and Quality of Life in Patients With Cataract in Northwestern Nigeria. Nigerian Journal of Ophtalmology. 24(2). 57-61.

13. Paula, T.D.M., Leonardo, T.D.M., Rosa, A.A.M., \& Silveira, L.C.D.L. (2014). Life Quality Assesment of Patients After Phacoemulsification or Extracapsular Cataract Extraction. Arq Bras Oftalmol. 77(1). 12-16.
14. Mehmet, B., \& Abuzer, G. (2009). Results of Cataract Surgery in the Very Elderly Population. J Optom, 2, 138141. 